therefore, now rests upon them, for he upon whom their choice falls will not be merely the representative of English science in London, he will represent it on the Continent and in America; the choice must bear the criticism of scientific men in other lands. EDITOR

\section{SIR EDWARD SABINE}

$S^{P}$ OTTISWOODE, round whose grave in Westminster Abbey so many men, great in so many ways, have stood to-day, is not the only President of the Royal Society, and not the only man of science whose loss we have to deplore. While one, however, was cut off in the full tide of his life, and while there seemed to be a rich promise of many years of valuable work in store, the other had far outlived his working powers, and by many years exceeded those of his activity.

A reference to the life-work of Sabine will clearly show how justly his high position and reputation were accorded to him, how nobly he has worked in the cause of science, and how imperishable a record of his life remains in the existence of a whole branch of scientific research, the foundation of which was mainly due to his untiring industry.

Coming of an old family said to be of Italian origin, which early settled in Normandy, and removed thence to our own country, Edward Sabine was born in Dublin on October 14, 1788, being the son of Mr. Joseph Sabine of Tewin. He received his early education at the Royal Military Colleges of Marlow and Woolwich, obtaining a commission as second lieutenant when but fifteen years of age, and receiving his captaincy eleven years later.

Very early in life indeed, his interest became centred in physical science, and especially in magnetism, the study of which he pursued with indefatigable zeal and marked success. The result of his work in this and other fields is to be found in the many papers which issued from his pen. In 1818 , six years before Spottiswoode was born, he was elected a member of the Royal Society, and in the same year was appointed astronomer to the expedition under the command of Sir John Ross which left England in search of the North-west Passage. The careful observations which he made whilst with the expedition were of great value. His publisbed papers begin from this date, commencing with a contribution to the Transactions of the Linnean Society, on the birds of Greenland, the result of observations made during the voyage; they range from that date down to the year 1872 , thus extending over a period of no less than fifty-four years.

During this long period of active work he contributed to the Transactions and Proceedings of various societies and contemporary magazines upwards of one hundred papers, some of great length and many of considerable value and importance. Although a large number of these deals with the subject of terrestrial magnetism, many other branches of science are included in them, the voluminous nature of his published works being not less remarkable than the wide fields of study over which they range.

A considerable number are to be found in the Philosophical Transactions, to which he contributed upwards of forty. To the Proceedings of the Royal Society he made numerous contributions during his long association with it ; in the Quarterly Journal of Science he published twelve papers, in the Reports of the British Association we find ten, to the Philosophical Magazine he made eight contributions, the remainder of his published works being scattered among the Edinburgh Journal of Science, Journal of the Geographical Scciety, the Proceedings of one or two foreign societies, and the pages of foreign scientific magazines.

As we have already said, his scientific contributions date from his voyage to the Arctic regions with Sir John Ross in 1818. Next year he again went to the Arctic regions, this time with an expedition under the command of Sir Edward Parry. As the result of his observations there, he made two communications to the Royal Society, published in the Philosophical Transactions, dealing, the one with the irregularities observed in the direction of the compass needle consequent upon the attraction of the iron of the ships, the other with the variations of the magnetic needle, and the intensity of the magnetic force during the voyage, and calling attention for the first time to the extreme importance of founding a widely extended series of observations of those strange magnetical disturbances, the origin of which is still mysterious. With this object in view he left England two years later on a long voyage in H.M.S. Pheasant, making numerous observations and bringing many new facts to light. At the same time at several equatorial stations on the coasts of Africa and America he made observations with regard to the swinging of the pendulum, with the object of determining the true figure of the earth, publishing the results in the Philosophical Transactions. When on the American coast during this voyage he took up amongst other subjects the question of deep-sea temperatures, and in the Philosophical Transactions for 1823 , he at that early period published a paper on the temperature at great depths in the Caribbean Sea, whilst in the same year his busy pen was giving an account of the barometrical measurement of the height of the Sugarloaf Mountain at Sierra Leone, and the Pico Ruivo in the Island of Madeira. Three years later he published in the Quarterly Journal of Science an account of the ocean currents met by H.M.S. Pheasant during the voyage from Sierra Leone to Bahia, and thence to New York, in which he records that the Amazon stream was crossed at a distance of 300 miles from the mouth of the river. In this year (1823) he proceeded on another voyage, going this time in H.M.S. Griper to Norway, Greenland, and Spitzbergen, to continue his magnetical observations, and to extend the series of pendulum experiments. Whilst at the latter place he again took up the question of barometrical measurement of heights, publishing in the Philosophical Transactions for 1824 a comparison of that method of measurement with the trigonometrical determinations. Then in the Edinburgh Journal of Science in 1825 he dealt with the presence of the Gulf Stream on the coasts of Europe as determined by his observations in the year 1822 , and proceeded to discuss the question of depression over the region occupied by the Stream.

In 1826 an account of his magnetical observations at Spitzbergen appeared in Poggendorff's Annalen.

Continuing his pendulum swingings in 1827 , he set about determining by direct observation the difference in 
he lengths of the seconds pendulum at Paris and London. The results of these experiments were published in a paper of some length which appeared in the Philosophical Transactions for 1828 . At the same time he also experimented with the object of ascertaining the ratio of the magnetic forces acting on a needle horizontally suspended in London and in Paris. In 1829, in the Philosophical Transactions, he wrote on the reduction to a vacuum of the vibrations of an invariable pendulum; and in the Quarterly Journal of Science for the same year he gave an account of experiments concerning the force of the earth's magnetism, and on the then recent magnetical observations in Siberia of M. Hanstein. In the Philosophical Transactions for $183 \mathrm{r}$ he describes some experiments made with the object of determining the length of the seconds pendulum at Green wich.

For many years from this date he worked mainly at that science on which he had most deeply set his mark, that of terrestrial magnetism. In 1835, in conjunction with Lloyd, Humphrey, and J. C. Ross, he contributed to the Reports of the British Association (of which he was an early and active member, filling the post of General Secretary for twenty-one years) an account of the terrestrial magnetic force in Ireland. In the following year he himself published in the Reports of that Association an account of the magnetic force in Scotland. As an indication of his range of subjects we may here remark that at this time he published in Froriep Notizen a paper concerning the volcanoes of the Sandwich Islands. Then in 1837 we find him again contributing to the British Association Reports, this time a paper on magnetic intensity, dealing with the variations it exhibits at different parts of the earth's surface. He also wrote on the same subject two years later in Froriep Notizen, L'Institut, and Quetelet's Mathematical Correspondence. In 1838 a memoir on the magnetic isoclinal and isodynamic lines in the British Isles appeared in the British Association Reports, being prepared from observations made by Prof. $\mathrm{H}$. Lloyd, J. Phillips, R. W. Fox, Capt. J. C. Ross, and the indefatigable Sabine. In 1840 he continued his papers on terrestrial magnetism in the Philosophical Transactions, now taking for his subject the consideration of lines of equal inclination and intensity in the Atlantic Ocean, and on lines of magnetic intensity between the Cape of Good Hope and Australia. He added to this series in the following year by contributing an account of the observations made by Capt. Belcher on the west coast of America and adjacent islands, and the new determination of magnetic elements at Otaheite. Writing in 1838 Sabine had so conclusively demonstrated the importance of magnetical observations being made in every part of the globe, that Capt. James Ross was sent with the Erebus and Terror to make a magnetical survey of the Antarctic regions. Sabine of course accompanied the expedition. In extension of the work of the magnetic observatory which he had established in England, and which was carried on entirely by his influence, Sabine had induced the authorities to promote the establishment of observatories in the colonies. On the voyage out, therefore, not only were numerous observations made, but magnetical and meteorological observatories were founded at St. Helena, the Cape, and Van Diemen's Land, thus permitting a great increase in the number of possible observa- tions, and a consequent more rapid advance of the science which Sabine had so much at heart. These observatories - to our disgrace be it said, some have now been abolished -were placed under the superintendence of Sabine, and at this period a general magnetic survey of the globe was commenced by him under the direction of the Admiralty, although from what has gone before it is easy to see that the initiative of such a gigantic task had come from himself

In 1842 he yet further added to his contributions to terrestrial magnetism, publishing in the Philosophical Transactions an account of observations made during the voyage of the Erebus and Terror from England to the Cape, and from thence to Kerguelen Island. Then in I 843 he wrote concerning the extension of these observations from Kerguelen Island to Van Diemen's Island, giving an account also of the various observations made in the Antarctic circle itself during the summer of 1840 and 1841 , adding in the year following (I844) an account of the observations from June, I84I, to August, 1842, in the same region. In 1844 and 1845 he made contributions to the British Association Reports concerning the meteorology of Toronto and Bombay. During 1846 he again made contributions to meteorological literature, discussing the winter storms of the United States, and the cause of the mild winters which occur sometimes in our own country.

With reference to the survey of the globe to which we have referred, we find him next giving an account of a magnetic survey of a considerable portion of the North American continent, and of the southern hemisphere between the meridian of $0^{\circ}$ and $125^{\circ}$ east, and parallels of $-20^{\circ}$ and $-70^{\circ}$. In 1849 , in another contribution, he gave a map of the magnetic declination for 1840 in the Atlantic Ocean, between the parallels of $60^{\circ} \mathrm{N}$. and $60^{\circ}$ S. latitude. In this year it was that Humboldt's Cosmos, for the author of which Sabine had a profound admiration, began to be issued in England, being translated by Mrs. Sabine, and edited by her husband, it being completed in 1858 . In the year following he became vicepresident of the Royal Society, with which he had been so long connected.

The colonial observatories were, as we have said, under the control of Sabine, and remained so for many years. In 1851 and 1852 , and again in 1856 , he continued bis papers on the magnetism of the earth.

It had been observed (first by Lamont) that the mean of the larger magnetic disturbances gave signs of being bound by some law, and of having a definite but longperiod variation. Previously to this it had been shown by Schwabe that the number of spots on the surface of the sun increased and decreased in obedience to regular law, the cycle occupying nearly eleven years for its completion. The results of the observations at the colonial observatories led Sabine to the discovery that magnetical disturbances were intimately bound up with this solar spot period; that the connection between them was of such a nature, that a year of large declination coincided with a year of maximum sunspots, whereas those years when the range in declination was small corresponded with years when there were but few spots on the sun. In the same year the same fact was independently determined by Dr. Rudolf Wolf and M. Gautier. 
In 1853 , at the meeting of the British Association at Belfast, Sabine occupied the presidential chair. In this year he turned to a consideration of the moon's influence on terrestrial magnetism, writing concerning the effect of that body on the magnetic declination at Toronto, St. Helena, and Hobarton; and taking up the subject again in 1856 , he then discussed the lunar diurnal variation at Toronto. At a later period, in the Proceedings of the Royal Society, he contributed a paper on the lunar diurnal magnetic declination obtained from the Kerw photograms. In 1857 he made another contribution to the British Association Reports, discussing the amount and frequency of the magnetic disturbances and of the aurora at Point Barrow, on the shores of the Polar Sea. In the Philosophical Transactions for the same year he discussed the question of the existence of the decennial period in the solar diurnal magnetic variations and its non-existence in the lunar diurnal variation of the declination at Hobarton, as M. Kreil seemed to think was the case. He then stated, as the result of a re-examination of the question by the light thrown upon it by the Hobarton observations, that he was as entirely convinced of the existence of this period in the former case as he was convinced of its non-existence in the latter.

Continuing the investigation of this subject, he contributed to the Royal Society Proceedings for 1859-60 a paper on the solar diurnal variation of the declination at Pekin. In the same volume of the Royal Society Proceedings he also wrote concerning the laws of the phenomena of the larger disturbances of the magnetical declination at Kew Observatory. In $\mathrm{I} 86 \mathrm{I}$, at the request of the General Committee of the British Association, he prepared a report on the repetition of the magnetic survey of England. In this year he succeeded Sir Benjamin Brodie in the presidency of the Royal Society, which position he occupied for the next ten years. In the Philosophical Magazine for $x 862$ he entered into a discussion concerning the cosmical origin of terrestrial magnetism. Two years later, both in the Philosophical Magazine and the Proceedings of the Royal Society, he published a comparison of the most notable disturbances of the declination at Kew and Nertschinsk during 1858 and 1859 . During the next few years, notably in 1866 and 1871 , records of the magnetical observations at Kew were published by him. The chief work, however, of this period of his life consisted in concluding his contributions to the Philosophical Transactions by reports and reductions of the work done during the Antarctic expedition. In a lengthy contribution in 1866 he resumed the discussion and zo-ordination of the various observations, continuing and concluding this in another paper, which is to be found in the Transactions for 1868 . His last contribution appeared in 1872 , when he gave a magnetical survey of the North Polar regions to serve as a companion to the survey of the South Polar regions which had already appeared. It was his earnest wish that he might be spared to complete this, but the infirmities of age were then stealing over him, and it is doubtful whether it would ever have appeared had it not been for the able assistance of Captain, now Sir Frederic Evans, the Hydrographer of the Admiralty, assistance which the author gracefully acknowledges in a postscript to the memoir.

From this date the work of Sabine may be said to have ceased. He had resigned the presidency of the Royal Society the previous year, and he now sought to spend the evening of his life in that retirement and rest to which his advanced age and great works so fairly gave him a claim. He had received the Copley Medal of the Royal Society in 1821 , and the Royal Medal of the same society in I 849. In I 869 he was made K.C.B. He possessed also the Prussian Order pour le mérite, and was either an honorary or corresponding member of many foreign societies. We mention these facts to show that he retired from his active life full of well-earned honours. In 1879 he lost his wife, who for more than half a century was the close companion of his labours. In the history of the Royal Society his name will ever be valued as that of one who, both as member and as President, was ever foremost in guarding its bonour and maintaining its dignity, whilst the kindness and courtesy which as President he displayed to all, not excluding the younger members, will be always gratefully remembered.

It is chiefly by his pendulum observations and by his magnetic determinations and reductions that, as may be gathered from what has been said, his name is so well known in science. The degree of accordance which some of the early determinations of the former kind exhibited was so much in advance of what was at that time thought likely, that they were received with incredulity in some quarters. The discussion which Sir George Airy made long ago, in his article on the figure of the earth, published in the "Encyclopædia Metropolitana," of the pendulum observations then available for that purpose, shows how large a share belonged to the labours of Sir Edward (then Captain) Sabine.

His own magnetic observations were marked by his wonted accuracy; and his discussion of the results obtained at the colonial magnetic observatories led to new and unexpected results. The most striking, perhaps, of these was the discovery of the relation between magnetic perturbations and the more or less spotted condition of the sun's surface, to which we have already referred. Dissimilar as are these phenomena, and difficult as it then at least was to imagine any possible cause for a connection between them, subsequent observations have fully confirmed the conclusion at which he arrived, that connected they are, though what the precise nature of the connection may be is still a matter of discussion.

Though from the nature of the case the work was one of compilation rather than of original observation, his determination of the magnetic state of the earth at a particular epoch, with its accompanying maps of the isoclinal, isogonal, and isodynamic lines was most noteworthy. The search for the original authorities and the application of the corrections requisite to render the observed results comparable with one another occupied a long time, and the resuits, as we have pointed out, appeared in instalments, as the various regions into which as a matter of convenience the earth's surface was divided were successively completed.

The establishment of the colonial observatories, too, was the direct result of his exertions; and his name will go down to posterity as that of the man who more than any other laboured for the proper establishment of the science of terrestrial magnetism, interesting and important 
in its scientific aspect, and pregnant with so many benefits to mankind at large.

He was buried on Saturday, his remains being placed beside those of his wife in the family vault at Tewin; the funeral, in accordance with his own wish, being of the simplest character. In addition to the members of his family and private friends, the funeral was attended by the Secretary and Treasurer of the Royal Society, the Hydrographer to the Admiralty, and representatives of the other Government services with which he had been so long connected.

\section{A MINISTER OF PUBLIC INSTRUCTION}

WE are a longsuffering, patient people. The call of Luther to those around him to educate their children and make men of them, as well as provide them with arms - a call at once answered in Germany -is only just now being answered among ourselves.

One of the most beautiful and one of the most touching sights in London now, and one which in our view is a standing disgrace to the politicians who have held sway during the last hundred years, is the gradual rising above dingy roofs and millions of chimneys of the red brick Board schools. The children in London at all events are now being educated, and our future masters are receiving the first rudiments of their instruction, and this much more on account of the intention of their fathers to have it for them, than on account of any farseeing policy of those who are popularly supposed to look in any and every direction for anything that may conduce to the well-being of our country. We have at last got a public instruction, and it is already in the air thai that instruction will in time be as free as it is now compulsory. It is a heartbreaking thing to look back and think what might have been had these all too recently built schools overtopped the squalid dwellings of the poor a century ago. How much less squalid those dwellings would be now. The monumental and extensive prisons would probably be less occupied in their every cell than they are now, but the well-being of the country, the output of the country would have been greater, and the struggle with penury, and dirt, and crime would have been less.

This is only one aspect of education, but yet it seems that in this country at all events it is the mainspring of public opinion with regard to the general question. The cry-on many grounds the mistaken cry-for technical instruction has grown from the work of the Board schools, it has gone along the same line at a higher level, and it will go on still further. The enormous development of the Government Science and Art Classes will also go on, and to the credit of the late Sir Henry Cole be it said here that he was wiser than the politicians, and his clear sight and singlemindedness influenced the head of the department with which he was connected, so that the quiet, slow work in science and art began in $185 \mathrm{I}$, long before the present notions of the importance of education really began to take root in our land.

Now that compulsory education is in our midst, now that the importance of science and of art to the national industries is universally acknowledged, now that it is recog. nised that the education of our workmen must no longer be so disgracefully neglected as it has been, it is again suggested that there should be a Minister to look after these matters.

Ten years ago, as it was well put, the Kinderpest was the care of the Government side by side with the Rinderpest. Both were practically on the same level, both were acknowledged to be nuisances, both might require a public department to look after them, and then money would have to be spent. This was quite a sufficient argument with "statesmen" to let things go on in the old harum-scarum way ; for the policy of a Government is to keep money in its purse, honestly if it can, but in any case to do so, as if England were a miser, acknowledging no responsibilities, spurning all delight; and wishing to live a sordid life like the burghers, caring only for their dykes and pikes, whom Luther shamed out of their indifference centuries ago.

There has again, this week, been a suggestion made that there should be a Minister of Public Instruction, who should be responsible for the preparedness of the country in this respect, just as the Minister of War is responsible for the preparedness of it in another direction. Sir John Lubbock must be congratulated upon the way in which he brought the motion forward last Friday. It was a mild, pleading story. As long ago as 1856 , he pointed out, the late Lord Derby said :-

"It appeared to him well worthy of consideration whether it would not be well to have a Minister, or the head of a department, who should have no other duties to perform, and who should be, in fact, responsible for the education of the people. ... He had a strong feeling that the institution of a Minister of Instruction was desirable, that the subject should be altogether separated from the Privy Council."

But that did no goot. In 1862 there was another resolution put to the House calling on it to affirm that for the education estimates and for the expenditure of all moneys for the promotion of education, science, and art a Minister of the Crown should be responsible to the House. That also did no good. In 1865 a Select Committee was moved for to inquire into the constitution of the Committee of the Council on Education. It was then urged that education and science and art were beginning to be considered of such importance that-

"The great duty of superintending the various branches connected with the Department of Education should be intrusted to some one responsible Minister, some Minister who should be regarded as a State officer of high authority who should have the sole conduct of that department, and be solely responsible."

And that was shelved.

Nine years later, in 1874 , the same view was urged, and the present Prime Minister then admitted "that there was much to be said in favour of the general principle that the expenditure of money for the promotion of education in science and in art should be placed under the control of a single responsible Minister." It is true he said this, but he supported the previous question, so that again came to nothing.

Now that education and science are the gr at things of the day, not only in this but in all countries, England enjoys the proud preeminence of being the only country -civilised country, we know nothing of Timbuctoo--in which there is not a Minister of Public Instruction. It is lamentable, terrible, to read the debate of last Friday, 